Jurnal Keperawatan Silampari (JKS)

Volume 3, Nomor 1, Desember 2019

e-ISSN :2581-1975

p-ISSN :2597-7482

DOI: https://doi.org/10.31539/jks.v3i1.534

\title{
AROMATERAPI KENANGA DIBANDING LAVENDER TERHADAP NYERI POST SECTIO CAESARIA
}

\author{
Wasis Pujiati ${ }^{1}$, Meily Nirnasari ${ }^{2}$, Hotmaria Julia Dolok Saribu $^{3}$, Daratullaila $^{4}$ \\ Stikes Hang Tuah Tanjungpinang ${ }^{1,2,3,4}$ \\ wasispujiati82@gmail.com ${ }^{1}$
}

\begin{abstract}
ABSTRAK
Penelitian ini bertujuan untuk membandingkan pengaruh aromaterapi kenanga dan lavender terhadap intensitas nyeri pasien post operasi Sectio caesaria. Metode penelitian ini menggunakan desain true experimental, rancangan randomized pretest posttest design. Teknik sampling dengan simple random sampling. kelompok intervensi I diberikan aromaterapi kenanga dan kelompok II diberikan aromaterapi lavender. Perubahan intensitas nyeri diukur menggunakan Numerical Rating Scale. Nyeri yang dirasakan pasien sebelum melakukan penghirupan aromaterapi kenanga adalah ratarata 5,00 (nyeri sedang) dan sesudah terapi sebesar 3,25 (nyeri ringan). Nyeri yang dirasakan pasien sebelum melakukan penghirupan aromaterapi lavender adalah ratarata 4,83 (nyeri sedang) dan sesudah terapi sebesar 3,25 (nyeri ringan). Hasil analisis dengan uji Wilcoxon ( $p$ value 0,000) menunjukkan ada pengaruh intervensi aromaterapi kenanga dan lavender menggunakan teknik inhalasi terhadap intensitas nyeri pasien post sectio caesaria. Hasil Uji Mann Whitney didapatkan $p$ value 0,054. Simpulan tidak ada perbedaan yang signifikan pengaruh intervensi dari kedua kelompok, artinya kedua intervensi mempunyai efektivitas pengaruh yang sama dalam penurunan intensitas nyeri pasien post sectio sesarea.
\end{abstract}

Kata Kunci : Aromaterapi Kenanga, Lavender, Nyeri, Sectio Saesaria

\section{ABSTRACT}

This study aims to compare the effect of cananga and lavender aromatherapy on pain intensity in postoperative patients with Sectio caesaria. This research method uses true experimental design, randomized pretest posttest design. Sampling technique with simple random sampling. intervention group I was given aromatherapy cananga and group II was given lavender aromatherapy. Changes in pain intensity are measured using a Numerical Rating Scale. The pain felt by patients before inhaling cananga aromatherapy is an average of 5.00 (moderate pain) and after therapy of 3.25 (mild pain). Pain that was felt by patients before inhaling lavender aromatherapy was an average of 4.83 (moderate pain) and after therapy of 3.25 (mild pain). The results of the analysis with the Wilcoxon test ( $p$ value 0,000) showed that there was an influence of cananga and lavender aromatherapy interventions using inhalation techniques to the intensity of pain in post sectio caesaria patients. Mann Whitney Test results obtained p value 0.054. Conclusions There is no significant difference in the effect of intervention from the two groups, meaning that both interventions have the same effective effect in reducing the intensity of pain in post-sectional cesarean patients.

Keywords: Aromatherapy Canangium Odoratum, Lavandula, Pain, Sectio caesaria 


\section{PENDAHULUAN}

Persalinan merupakan proses membuka dan menipisnya serviks, dimana janin dan ketuban didorong keluar melalui jalan lahir (Prawiroharjo, 2009) Sectio caesaria adalah suatu pembedahan guna melahirkan anak lewat insisi pada dinding abdomen dan uterus (Oxorn, 2010). Menurut World Health Organisation (WHO) standar rata-rata sectio caesaria di sebuah negara adalah sekitar 5-15\%. Di rumah sakit pemerintah ratarata $11 \%$ sementara di rumah sakit swasta bisa lebih dari 30\%. Tahun 2004 angka kejadian sectio caesaria di Inggris sekitar 20\% dan 29,1\%. Sedang pada tahun 20012003 angka kejadian sectio caesaria di Kanada adalah 22,5\% (Dewi, 2007).

Pada tahun 2016 berdasarkan data Rekam Medik di RSUD Raja Ahmad Thabib Provinsi Kepulauan Riau dengan jumlah kasus secsio sesarea sebanyak 576 kasus, berdasarkan wawancara di Ruang Obstetri dan Ginekologi kisaran ibu post seksio sesarea 8-12 pasien dengan rata-rata angka perbulannya mencapai 32-48 kasus. Dari studi pendahuluan yang dilakukan oleh peneliti, hampir seluruh pasien yang menjalani sectio caesaria menggunakan anestesi regional, yaitu anestesi spinal, dengan rata-rata lama perawatan selama 4-5 hari, selain itu obat-obatan yang digunakan dalam mengatasi nyeri adalah obat-obatan anti nyeri (analgesik) yang diberikan secara injeksi maupun didrip kedalam cairan intravena. Tindakan pembedahan pada sectio caesaria tentunya akan mengakibatkan dampak berupa nyeri akibat luka sayatan. Nyeri sectio caesaria merupakan hal yang wajar ketika efek pembiusan yang telah habis. Nyeri umumnya digambarkan sebagai pengalaman sensori dan emosional yang tidak menyenangkan akibat kerusakan jaringan yang aktual dan potensial (Judha et al., 2012).

Pasien dengan sectio caesaria umumnya akan mengeluh nyeri disekitar luka operasi. Nyeri ini mengakibatkan seseorang cenderung enggan untuk bergerak dan takut untuk melakukan aktifitas sehingga akan ada kemungkinan untuk terjadi deep vein thrombosis yang disebabkan meningkatnya kekentalan darah karena mekanisme hemokonsentrasi yang terjadi pada ibu pasca melahirkan. Selain itu, membatasi pergerakan dapat memperlambat proses penyembuhan luka, dengan lamanya proses penyembuhan luka ini akan mengakibatkan besarnya biaya perawatan yang akan ditanggung oleh pasien.Penanganan terhadap nyeri terbagi menjadi dua cara yaitu, cara farmakologis dan non farmakologis. Secara farmakologis, penanganan nyeri pada pasien sectio caesaria dilakukan dengan pemberian obat-obatan anti nyeri (analgesik) baik secara oral maupun injeksi. Selain terapi farmakologis penanganan nyeri dapat juga dilakukan dengan beberapa terapi non farmakologis seperti terapi accupressure, mengubah posisi pasien senyaman mungkin, melakukan teknik distraksi, teknik relaksasi, terapi akupuntur, aromaterapi.

Khususnya di Kepulauan Riau belum terdapat pengobatan yang menggunakan terapi komplementer seperti aromaterapi dalam mengatasi masalah kesehatan. Aromaterapi hanya dapat dijumpai ketika berada ditempat-tempat perawatan tubuh dan kecantikan dan dengan harga yang cukup mahal. Aromaterapi merupakan pengobatan yang berasal dari minyak esensial dari tanaman. Minyak tersebut dapat diserap ke dalam tubuh melalui kulit ataupun sistem penciuman, aroma yang dihasilkan mengaktifkan indra penciuman (Hur et al., 2011). Aromaterapi juga dikenal sebagai pengobatan aromatik, merupakan gabungan seni dan ilmu yang menggunakan minyak tumbuhan untuk kesehatan, kesejahteraan, dan pengobatan (Raphael et al., 2002). Berbagai jenis minyak esensial digunakan untuk aromaterapi, seperti melissa, eucalyptus dan lavender. Minyak tersebut bersifat rileksasi, mengurangi nyeri, stres, dan meningkatkan kesehatan (Apay et al., 2012). 
Selain itu aromaterapi juga dapat digunakan sebagai terapi pelengkap dalam penanganan nyeri pasien sectio caesaria .Terapi ini bisa dilakukan dengan berbagai macam metode seperti pijat, inhalasi, oral, dan air. Akses aromaterapi melalui hidung (inhalasi) adalah rute yang efektif dan jauh lebih cepat dibandingkan dengan cara lain. Aroma yang berasal dari minyak kenanga atau lavender yang diletakkan didalam tabung (roll on) akan ditangkap oleh reseptor di hidung dan kemudian memberikan informasi lebih jauh ke area di otak yang mengontrol emosi dan memori maupun memberikan informasi juga ke hipotalamus yang mengatur sistem internal tubuh, suhu tubuh dan reaksi terhadap stress (Koensoemardiyah, 2009).

Penelitian ini bertujuan untuk mengetahui intensitas nyeri dalam pemberian minyak aromaterapi kenanga ataupun aromaterapi lavender untuk rileksasi dan menurunkan intensitas nyeri yang dirasakan oleh pasien post section Caesaria.Berdasarkan uraian diatas, maka penulis tertarik untuk membuktikan "Bagaimana pengaruh aromaterapi kenanga dibanding lavender terhadap intensitas nyeri pasien post sectio caesaria di Ruang Obstetri dan Ginekologi RSUD Provinsi Kepulauan Riau".

\section{METODE PENELITIAAN. Jenis Penelitian}

Penelitian ini menggunakan desain true experimental dengan rancangan randomized pretest posttest design, yaitu membandingkan subjek sebelum dan sesudah diberikan aromaterapi kenanga dan aromaterapi lavender terhadap nyeri pada pasien post sectio caesaria. Populasi dalam penelitian berjumlah 48 orang. Sampel dalam penelitian ini adalah 24 orang.

\section{Tempat dan Waktu Penelitian}

Penelitian ini dilakukan pada pasien post sectio caesaria yang mengalami nyeri pada bulan Maret -Juli 2017.

\section{Populasi, Sampel dan Teknik Sampling}

Populasi dalam penelitian ini adalah jumlah rata-rata kasus sectio caesaria perbulan sepanjang tahun 2014 yaitu 48 orang. Sampel dalam penelitian ini adalah pasien sectio caesaria di Ruang Obstetri dan Ginekologi RSUD Provinsi Kepulauan Riau yang memenuhi kriteria dan diambil menggunakan cara dari Surakhmad (1994) dalam Notoatmodjo (2010) yang menyatakan apabila jumlah populasi sebanyak kurang lebih dari 100, maka pengambilan sampel sekurang-kurangnya 50\% dari ukuran populasi. Populasi dalam penelitian ini adalah rata-rata pasien sectio caesaria sepanjang tahun 2016 berjumlah 48 orang dan jika diambil berdasarkan cara Surakhmad maka jumlah sampel dalam penelitian ini adalah 48:50\%=24 orang, untuk kelompok Kenanga dan kelompok lavender. Pengambilan sampel pada penelitian ini menggunakan pendekatan simple random sampling yaitu pasien berdasarkan nomor urut, pasien post Sectio caesaria dengan nomor genap masuk ke kelompok kenanga dan nomor ganjil kelompok lavender. Dalam penelitian ini, peneliti menetapkan 24 orang sebagai sampel dari jumlah populasi. 


\section{Prosedur Penelitian}

\section{Tahap Persiapan}

Dalam tahap ini peneliti mempersiapkan alat dan bahan yang digunakan dalam penelitian. Minyak aromaterapi kenanga dan lavender yang dipergunakan diperoleh dari Lansida Herbal Technology. Pembelian dilakukan lewat online, Minyak lavender diekstraksi melalui proses penyulingan uap dari bunga lavender. Aromaterapi kenanga mengandung senyawa aktif berguna seperti flavonoid. Saponin, polifenol, minyak atsiri, eugenol, dan geraniol. Aromaterapi lavender adalah campuran asetat linalyl alam dan linalool. Komponen utama minyak ini adalah asetat linalyl (35\%) dan linalool (51\%).. Dengan demikian berdasarkan proses pembuatannya, minyak esensial dari produk Lansida Herbal Technology merupakan minyak esensial yang aman untuk digunakan. Kemudian setelah menyiapkan bahan melakukan pelarutan minyak esensial berdasarkan perbandingan yang telah ditetapkan (konsentrasi $3 \%$ yaitu $3 \mathrm{ml}$ aromaterapi kenanga atau lavender dilarutkan dengan $100 \mathrm{ml}$ minyak olive oil dan memasukkan minyak ke dalam botol. Minyak aromaterapi lavender dan kenanga diberikan label nama supaya tidak tertukar.

\section{Tahap Pelaksanaan}

Penentuan pemberian kenanga atau lavender adalah dengan teknik simple random sampling yaitu berdasarkan nomer urut, pasien yang datang pertama kali yang mengalami nyeri post sectio caesaria hari ke 2 dianggap nomer 1 dan yang kedua dianggap nomer 2 . Untuk nomer urut ganjil atau dimulai oleh pasien sectio caesaria yang datang dengan nyeri pada urutan ke 1 dimasukkan ke dalam kelompok perlakuan I (kelompok kenanga) dan nomer urut genap dimulai oleh pasien post sectio caesaria nomer 2 dengan nyeri dimasukkan ke dalam kelompok perlakuan II (kelompok lavender) sampai terpenuhi sampel yang telah ditetapkan.

Kemudian Peneliti mendatangi lokasi penelitian untuk melakukan pencocokan kriteria inklusi pada pasien sectio caesaria yang akan dijadikan sebagai responden. Setelah mendapatkan responden yang bersedia dijadikan subjek penelitian dan meminta responden untuk menandatangani lembar persetujuan, kemudian peneliti melakukan proses pengumpulan data yang terdiri dari pretest dan posttest. Pada tahap pretest, peneliti menjelaskan tujuan penelitian dan kemudian mengkaji skala nyeri responden dengan menggunakan numeric rating scale 0-10. Responden diminta untuk mengatakan pada angka berapa yang nyeri yang ia rasakan.

Tahap Pemberian aromaterapi setelah melakukan pretest, peneliti akan memberikan aromaterapi kenangaatau lavender yang sudah dikemas dalam bentuk roll on kepada responden dan mengajarkannya menggunakan sesuai dengan prosedur, yaitu Pada terapi inhalasi, dosis yang dianjurkan yaitu melarutkan 10-15 tetes minyak esensial murni kedalam 1 liter air mendidih untuk satu kali pemakaian. Dalam terapi inhalasi, kita bisa juga menggunakan campuran dari tiga macam minyak esensial sekaligus dalam satu larutan. Terapinya sendiri dapat diberikan satu kali per hari untuk pemakaian selama 6 minggu berturut-turut atau dalam satu kali perminggu selama 30 minggu berturut-turut.

Untuk terapi inhalasi dapat menggunakan campuran antara minyak esensial murni dengan minyak basal yang dilarutkan bersama-sama. Konsentrasinya dapat memakai pengenceran 1-2,5\%. Pengenceran 1\% tersebut bahwa sekitar 5-6 tetes minyak esensial dapat dilarutkan kedalam $100 \mathrm{ml}$ minyak dasar atau untuk setiap tetes minyak esensial (3-4 tetes) dalam $20 \mathrm{ml}$ pelarut. Campuran ini dapat digunakan dalam terapi pengobatan 
yang dibantu dengan menggunakan peralatan aromaterapi.Terapi melalui inhalasi ini memiliki kontraindikasi pada klien dengan riwayat asma. Selain cara di atas terapi inhalasi ini juga dapat menggunakan cara dengan mengisi minyak esensial kedalam tabung (roll on) dan digunakan dengan cara menghirup aroma dari minyak esensial.

Tahap Posttest ini merupakan tahap terakhir dalam tahap pelaksanaan penelitian ini. Pada tahap posttest ini, peneliti kembali mengukur skala nyeri responden dengan menggunakan NRS (Numeric Rating Scale) NRS digunakan untuk menilai intensitas atau derajat keparahan nyeri dan memberi kesempatan kepada klien untuk mengidentifikasi keparahan nyeri yang dirasakan (Potter dan Perry, 2006).numeric rating scale 0-10 Interpretasi NRS adalah sebagai berikut: a) Tidak ada nyeri (skala 0), b) Nyeri ringan (skala 1-3), c) Nyeri sedang (skala 4-6), d) Nyeri berat (skala 7-9).

Responden diminta kembali mengatakan pada angka berapa ia merasakan nyeri setelah 5-10 menit pemberian aromaterapi. Tahap akhir data dikumpulkan dengan mengukur skala nyeri responden sebelum dilakukan perlakuan (pretest) dan sesudah diberikan perlakuan (posttest). Selanjutnya peneliti melakukan analisa data dengan menggunakan metode statistik. Selanjutnya diakhiri dengan penyusunan laporan akhir dan penyajian hasil penelitian.

\section{Pengolahan dan Analisa Data}

Sebelum melakukan uji hipotesis, peneliti melakukan interpretasi data untuk kelompok kenanga maupun lavender apakah data yang diperoleh terdistribusi normal atau tidak karena penyajian data dan uji hipotesis yang digunakan tergantung dari normal atau tidaknya distribusi data. Peneliti menggunakan uji normalitas data secara analisis menggunakan uji Shapiro Wilk karena jumlah sampel pada setiap kelompok yang diteliti kurang dari 50 orang. Data dikatakan terdistribusi normal apabila nilai $\mathrm{p}>0,05$ dan dikatakan tidak normal apabila nilai $\mathrm{p}<0,05$. Uji hipotesis untuk kelompok aromaterapi kenanga atau kelompok lavender, karena data yang didapatkan tidak terdistribusi normal maka menggunakan Uji Wilcoxon (non parametric wilcoxon test) dan untuk mengetahui keefektifan keduanya menggunakan Uji Mann Whitney (Dahlan, 2013).

\section{HASIL PENELITIAN}

Tabel 1.

Distribusi Frekuensi Responden Post Sectio caesaria sebelum dan sesudah diberikan Aromaterapi Lavender

\begin{tabular}{ccccc}
\hline \multirow{2}{*}{ Nyeri } & \multicolumn{2}{c}{ Pre } & \multicolumn{2}{c}{ Post } \\
\cline { 2 - 5 } & $\mathrm{N}$ & $\%$ & $\mathrm{~N}$ & $\%$ \\
\hline Ringan & 0 & 0 & 16 & 66,66 \\
Sedang & 22 & 91,66 & 6 & 25 \\
Berat & 2 & 8,3 & 2 & 8,3 \\
\hline Total & 24 & 100 & 24 & 100
\end{tabular}

Berdasarkan tabel 1 menunjukkan responden post sectio cesarea kelompok lavender sebelum diberikan aromaterapi lavender yang mengalami nyeri sedang sebanyak 22 pasien $(91,66 \%)$, nyeri berat sebanyak 2 pasien $(8,3 \%)$. Setelah diberikan aromaterapi lavender mengalami penurunan dengan nyeri ringan 16 pasien $(66,66 \%)$ dan nyeri sedang 6 pasien $(25 \%)$ dan nyeri berat 2 pasien $(8,3 \%)$. 
Berdasarkan tabel 2 dibawah ini, menunjukkan pasien post Sectio caesaria kelompok kenanga sebelum diberikan aromaterapi kenanga yang mengalami nyeri sedang sebanyak 22 pasien $(91,66 \%)$, nyeri berat sebanyak 2 pasien $(8,3 \%)$. Setelah diberikan aromaterapi kenanga mengalami penurunan dengan nyeri ringan 17 pasien $(70,83 \%)$, nyeri sedang 7 pasien $(29,16 \%)$.

\section{Tabel 2.}

Distribusi Frekuensi Responden Berdasarkan Nyeri Post Sectio caesaria Sebelum dan Sesudah diberikan Aromaterapi Kenanga

\begin{tabular}{lcccc}
\hline \multirow{2}{*}{ Nyeri } & \multicolumn{2}{c}{ Pre } & \multicolumn{2}{c}{ Post } \\
\cline { 2 - 5 } & $\mathrm{N}$ & $\%$ & $\mathrm{~N}$ & $\%$ \\
\hline Ringan & 0 & 0 & 17 & 70,83 \\
Sedang & 22 & 91,66 & 7 & 29,16 \\
Berat & 2 & 8,3 & 0 & 0 \\
\hline \multicolumn{1}{c}{ Total } & 24 & 100 & 24 & 100 \\
\hline
\end{tabular}

Tabel 3.

Analisis Uji Pengaruh Aromaterapi Lavender Terhadap Nyeri Pada Post Sectio caesaria dan Rentang Nyeri

\begin{tabular}{lccc}
\hline & \multicolumn{3}{c}{ Intensitas nyeri } \\
\hline Perlakuan & Mean & Rentang & $p$ value \\
\hline Sebelum & 4,833 & $4,00-7,00$ & 0,000 \\
Sesudah & 3,25 & $1,00-6,00$ & \\
\hline
\end{tabular}

Berdasarkan tabel 3 uji yang digunakan untuk mengetahui pengaruh pada perlakuan aromaterapi lavender ialah uji wilcoxon. Uji ini digunakan karena data dua kelompok yang tidak berpasangan. Berdasarkan tabel didapatkan $p$ value $0,000<0,05$ sehingga (Ho Ditolak) yang menyimpulkan ada pengaruh yang signifikan terhadap penurunan nyeri post sectio caesaria menggunakan aromaterapi lavender dengan teknik inhalasi.

Tabel 4.

Analisis Uji Pengaruh Aromaterapi Kenanga Terhadap Intensitas Nyeri Post Sectio caesaria dan Rentang Nyeri

\begin{tabular}{lccc}
\hline & \multicolumn{3}{c}{ Intensitas nyeri } \\
\hline Perlakuan & Mean & Rentang & P value \\
\hline Sebelum & 5,00 & $4,00-7,00$ & 0,000 \\
Sesudah & 3,25 & $1,00-6,00$ & \\
\hline
\end{tabular}

Berdasarkan tabel 4 uji yang digunakan untuk mengetahui pengaruh pada perlakuan aromaterapi kenanga dengan teknik inhalasi ialah uji wilcoxon. Uji ini digunakan karena data dua kelompok yang tidak berpasangan. Berdasarkan tabel didapatkanp value $0,000<0,05$ sehingga (Ho Ditolak) yang menyimpulkan ada pengaruh yang signifikan terhadap penurunan intensitas nyeri menggunakan aromaterapi kenanga dengan teknik inhalasi.

Berdasarkan tabel 5 dibawah ini, uji yang digunakan untuk mengetahui perbedaan pada perlakuan aromaterapi lavender ialah uji Mann-Whitney. Uji ini digunakan untuk 
mengetahui perbandingan antara dua kelompok yang tidak berpasangan. Analisa uji Mann-Whitney diperoleh $p$ valuesebesar 0,054 ( $p>0,005)$ dimana Ho diterima, sehingga dapat disimpulkan bahwa tidak ada perbedaan efek aromaterapi kenanga dengan lavender dalam intensitas nyeri post sectio caesaria. Hal ini menunjukkan bahwa kenanga dengan lavender memiliki efek yang sama dalam penurunan intensitas nyeri pada pasien post sectio caesaria .

Tabel 5.

Analisis Uji Perbandingan Aromaterapi Kenanga dibanding Lavender

Terhadap Intensitas Nyeri pada pasien post sectio caesaria

\begin{tabular}{|c|c|c|c|c|c|c|}
\hline \multirow[b]{2}{*}{ Nyeri } & & \multicolumn{2}{|c|}{ Pre } & \multicolumn{2}{|c|}{ Post } & $p$ value \\
\hline & & $\mathrm{N}$ & $\%$ & $\mathrm{n}$ & $\%$ & \multirow{8}{*}{0,054} \\
\hline \multirow{3}{*}{$\begin{array}{c}\text { Lavender } \\
\quad(\mathrm{N}=\mathbf{2 4})\end{array}$} & Ringan & 0 & 0 & 16 & 66,66 & \\
\hline & Sedang & 22 & 91,66 & 6 & 25 & \\
\hline & Berat & 2 & 8,3 & 2 & 8,3 & \\
\hline \multirow{3}{*}{$\begin{array}{c}\text { Kenanga } \\
(\mathrm{N}=\mathbf{2 4})\end{array}$} & Ringan & 0 & 0 & 17 & 70,83 & \\
\hline & Sedang & 22 & 91,66 & 7 & 29,16 & \\
\hline & Berat & 2 & 8,3 & 0 & 0 & \\
\hline \multicolumn{2}{|c|}{ Total } & 48 & 100 & 48 & 100 & \\
\hline
\end{tabular}

\section{PEMBAHASAN}

\section{Karakteristik Responden Kelompok Lavender dan Kenanga}

Berdasarkan tabel 3 menunjukkan bahwa frekuensi untuk usia sama antara kelompok lavender dengan kelompok kenanga dimana usia 20-30 tahun dan 31-36 tahun sebesar 50\%, sedangkan untuk hari post sectio caesaria pada hari ke 2 sebesar 20 $(83,33 \%)$ pasien untuk kelompok lavender dan sebesar 22 pasien $(91,66 \%)$ untuk kelompok kenanga. Respon nyeri seseorang dipengaruhi oleh salah satunya oleh usia dan pengalaman masa lalu. Anak-anak memiliki respon nyeri yang lebih tinggi bila dibanding dengan usia remaja, dewasa dan orang tua. Hal ini karena anak dapat mengekspresikan nyeri lebih bebas sedangkan pada remaja respon nyeri lebih rendah karena dapat mengontrol perilakunya. Individu yang pernah mengalami nyeri dimasa lalu bukan berarti mudah untuk beradaptasi terhadap nyeri yang dirasakan saat ini, namun individu akan lebih siap untuk melakukan tindakan-tindakan yang diperlukan untuk menghilangkan nyeri (Potter dan Perry, 2006).

Ibu yang berusia > 35 tahun memiliki tingkat nyeri yang semakin besar bila dibanding dengan usia $<35$ tahun. Ibu yang lebih tua mempunyai metabolisme yang lebih lambat bila dibandingkan dengan ibu yang berusia lebih muda, sehingga tingkat nyeri yang dirasakan juga akan berbeda.Individu akan mempersepsikan nyeri dengan cara yang berbeda-beda, berhubungan dengan bagaimana pengalaman seseorang terhadap nyeri dan cara mengatasinya.melalui Fisiologi Nyeri yaituReseptor Nyeri (nosiseptor) adalah organ tubuh yang berfungsi untuk menerima rangsang nyeri. Organ tubuh yang berperan sebagai reseptor nyeri adalah ujung syaraf bebas dalam kulit yang berespon hanya terhadap stimulus kuat yang secara potensial merusak (Tamsuri, 2007).Transmisi Nyeri pada seseorang terutama responden pada penelitian ini nosiseptor dapat menghasilkan rangsangan nyeri dan timbulnya nyeri. Beberapa teori 
yang berusaha menjelaskan tentang nyeri yaitu; 1) Teori Spesifitas (The Specificity Theory) adalah timbulnya sensasi nyeri berhubungan dengan pengaktifan ujung-ujung serabut saraf bebas oleh perubahan mekanik, rangsangan kimia, atau temperatur yang berlebihan. Persepsi nyeri yang dibawa oleh serabut saraf nyeri diproyeksikan oleh spinotalmik ke spesifik pusat nyeri di thalamus (Asmadi, 2008), 2) Teori Intensitas (The Intensity Theory) adalah hasil rangsangan yang berlebihan pada reseptor. Setiap rangsangan sensori punya potensi untuk menimbulkan nyeri jika intensitasnya cukup kuat (Asmadi, 2008), 3) Teori Kontrol Pintu (The Gate Control Theory) adalah impuls nosiseptif ditransmisikan melalui traktus spinotalamikus, tetapi dapat dimodulasi dalam medulla spinalis, batang otak atau kortek serebral (Otto, 2003).

\section{Pengaruh Aromaterapi Lavender Menggunakan Teknik Inhalasi}

Skala nyeri pada pasien kelompok aromaterapi lavender sebelum melakukan penghirupan menggunakan minyak adalah berada pada skala nyeri sedang 22 pasien $(91,66 \%)$ dan pada skala nyeri berat 2 pasien $(8,3 \%)$, sesudah dilakukan pemberian aromaterapi lavender secara inhalasi yang diletakkan di dalam botol roll on dan digunakan secara langsung di hirup maupun di oleskan dulu di tangan baru di hirup selama 5-10 menit. Sesudah dilakukan pemberian aromaterapi lavender secara inhalasi terdapat penurunan intensitas nyeri dari sedang menjadi ringan sebesar 16 pasien 66,66 $\%$. Dan 6 pasien masih merasakan dari nyeri sedang tetap mengalami nyeri sedang. Untuk nyeri yang dirasakan pasien sebelum melakukan penghirupan aromaterapi lavender adalah rata-rata 4,833 (nyeri sedang) dan sesudah 3,25 (nyeri ringan).

Pada hasil penelitian menggunakan aromaterapi lavender dengan inhalasi terdapat perbedaan yang signifikan sebelum dan sesudah dilakukan perlakuan. Berdasarkan tabel 3 untuk mengetahui pengaruh aromaterapi lavender dengan teknik inhalasi terhadap nyeri post sectio sesarea yang menggunakan analisis uji hasil $p$ value $0,000<0,05$, sehingga diketahui ada pengaruh penurunan nyeri post sectio sesarea sebelum dan sesudah diberikan aromaterapi lavender menggunakan teknik inhalasi.Kondisi nyeri yang dialami pasien merupakan respon subjektivitas dan persepsimasing-masing individu.

Nyeri adalah pengalaman pribadi, subjektif, berbeda antara orang yang satu dengan yang lain, dan dapat berbeda pada orang yang sama, pada waktu yang berbeda (Reeder et al., 2011). Nyeri menurut The International Association For The Study Pain (2005) adalah sensori yang dirasakan subjektif dan emosional yang tidak menyenangkan yang didapat terkait dengan kerusakan jaringan aktual maupun potensial, atau menggambarkan kondisi terjadinya kerusakan.

Sehingga pemberian aromaterapi levender merupakan tindakan yang dapat mendukung respon dan persepsi dari nyeri yang dirasakan oleh pasien, kandungan aromaterapi lavender yang mampu menurunkan nyeri yang di alami oleh pasien. Rasa nyeri dapat dipengaruhi oleh paritas, usia, kecemasan, dukungan keluarga, budaya dan lingkungan serta pengalaman persalinan sebelumnya (Judha, 2012).

Salah satu terapi non farmakologi yang digunakan dalam menurunkan intensitas nyeri adalah aromaterapi. Aromaterapi merupakan salah satu penanganan nyeri yang dapat digunakan untuk relaksasi. Aromaterapi yang digunakan pada penelitian ini adalahminyak lavender. Minyak lavender adalah salah satu aromaterapi yang paling umum digunakan dalam mengurangi nyeri dan rileksasi. Minyak lavender sangat cepat diserap oleh kulit, sehingga efeknya sangat cepat diketahui. 
Penggunaan teknik pengurangan rasa nyeri persalinan dapat dilakukan dengan metode nonfarmakologis seperti relaksasi, teknik pernafasan, perubahan posisi, massage, aromaterapi, hidroterapi, musik serta metode-metode lain yang dapat diterapkan. Aromaterapi adalah terapi komplementer dengan menggunakan minyak esensial yang diambil dari bau harum tumbuh-tumbuhan. Aromaterapi dapat diberikan dengan cara penghirupan, pengompresan, pengolesan dikulit, perendaman dan akan lebih efektif disertai pijatan (Bakir, 2009). Penggunaan aromaterapi dalam persalinan membantu ibu untuk menurunkan tingkat nyeri. Salah satu minyak aromaterapi yang bisa digunakan untuk mengurangi nyeri yaitu lavender. Minyak esensial lavender memiliki kandungan perelaksasi, antispasmodik dan pereda nyeri. Oleh sebab itu, lavender berguna untuk meredakan nyeri kontraksi terutama pada saat persalinan (Praptiani, 2012). Bau yang mengandung ion minyak atsiri yaitu lavender berbahan aktif linalool tersebut dibawa neuron menujusistem limbik untuk diteruskan ke hipotalamus. Di hipotalamus bau tersebut akan merangsang kelenjar pituitary untuk melepaskan agen kimia kedalam sirkulasi darah untuk mengatur kelenjar adrenal dan tiroid supaya menurunkan aktifitasnya yang sebelumnya dirangsang oleh adanya stimulus stressor yang menimbulkan reaksi hormon epineprin dan norepineprin. Bau ini juga merangsang daerah di otak yang disebut raphe nucleus untuk mengeluarkan sekresi serotonin yang menimbulkan efek rileks sebagai akibat inhibisi eksitasi sel (Carpenito, 2002). Aromaterapi lavender bermanfaat memberikan ketenangan, relaksasi, kecemasan, rasa nyaman dan mengurangi stres (sedatif), antispasmodik, analgesik, antiseptik, serta mengobati berbagai gangguan kulit. Pada pasien setelah diberikan pijatan aromaterapi lavender, menunjukkan terjadinya penurunan kecemasan dan penurunan tingkat nyeri.

Bau yang menyenangkan akan menciptakan perasaan tenang dan senang sehingga dapat mengurangi kecemasan. Selain itu, setelah ke limbik aromaterapi menstimulasi pengeluaran enkefalin atau endorfin pada kelenjar hipothalamus, PAG dan medula rostral ventromedial. Enkefalin merangsang daerah di otak yang disebut raphe nucleus untuk mensekresi serotonin sehingga menimbulkan efek rileks, tenang dan menurunkan kecemasan (Baehr, 2010).

Karena molekul minyak yang demikian kecil sehingga menembus ke dalam kulit dan memasuki sirkulasi darah dan langsung dipersepsikan ke otak. Minyak esensial tersebut mudah dikeluarkan dari badan dalam waktu 6-14 jam dan tidak meninggalkan sisa yang beracun sehingga sangat baik bagi tubuh (Dean, 2007).

Terapi melalui inhalasi memiliki efek yang baik, karna Sensor indera penciuman pada manusia memiliki tingkat kepekaan lebih tajam dan sensitif. Ketajaman indera penciuman ini dapat mencapai 10.000 kali lebih kuat daripada indera perasa.Karenanya terapi melalui inhalasi ini memiliki efek yang kuat terhadap organ-organ sensorik yang dilalui bahan aktif minyak esensial.Terapi inhalasi sangat berguna untuk mengatasi dan meringankan keadaan-keadaan yang berhubungan dengan kondisi tubuh seseorang. Adapun maksud dari terapi ini adalah untuk menyalurkan zat-zat yang dihasilkan oleh minyak esensial secara langsung dengan mengalirkan uap minyak esensial secara langsung atau melalui alat bantu aromaterapi seperti tabung inhaler dan spray, anglo, lilin, roll on atau pemanas elektrik. Zat-zat yang dihasilkan dapat berupa gas, tetes uap yang halus, asap serta uap sublimasi yang akan terhirup lewat hidung dan tertelan lewat mulut.

Aroma zat-zat minyak esensial akan membasahi bagian selaput lender pada hidung, faring, laring, trakea, bronkus, bronkhioli dan alveoli. Disamping itu, aroma 
minyak esensial ini juga bisa mempengaruhi kondisi psikis seseorang melalui rangsangan yang diterima oleh ujung-ujung saraf penciuman yang terdapat di dalam selaput lendir hidung atau daerah respon saraf pada organ lain yang dilalui aroma minyak esensial tersebut (Jaelani 2009) sesuai penelitian terkait inhalasi sangat berpengaruh dalam menurunkan nyeri menstruasi, karena molekul yang ada dalam minyak esensial yang dihirup memasuki paru-paru dan masuk kedalam aliran darah. Molekul tersebut berinteraksi dengan hormon dan enzim dalam darah sehingga mempengaruhi kimia seluruh tubuh. Molekul tersebut mempengaruhi sistem tubuh, menenangkan atau merangsang sistem kekebalan tubuh dan sistem saraf. Disamping itu bau merangsang sistem limbik dalam otak (pusat emosi dan memori), yang memicu perasaan dan mempengaruhi suasana hati (Dean, 2007).

Hal ini sejalan dengan penelitian yang dilakukan oleh Dwijayanti, 2014 bahwa terdapat perbedaan intensitas nyeri pasca sectio sesarea setelah pemberian aromaterapi lavender melalui inhalasi. Penelitian yang dilakukan (Widayani, 2016) aromaterapi Lavender dapat Menurunkan Intensitas Nyeri Perineumpada Ibu Post PartumTerdapat penurunan intensitas nyeri luka jahitan perineum sebelum dan setelah diberikan aromaterapilavender. Aromaterapi lavender berpengaruh secara signifikan terhadap penurunan nyeri luka jahitan perineum pada ibu post partum dengan p-value 0,01. Inhalasi aromaterapi lavender dapat digunakan sebagai alternatif terapi komplementer pada ibu post partum dengan luka jahitan perineum. Tetapi penelitian lebih lanjut dengan sampel yang lebih banyak dengan responden yang tidak hanya memiliki luka jahitan perineum derajat dua.

\section{Pengaruh Aromaterapi Kenanga Menggunakan Teknik Inhalasi Terhadap Nyeri Post Sectio caesaria}

Pada hasil penelitian menggunakan aromaterapi kenanga dengan teknik inhalasi terdapat perbedaan yang signifikan sebelum dan sesudah dilakukan perlakuan. Berdasarkan tabel 4 untuk mengetahui pengaruh aromaterapi kenanga dengan teknik inhalasi terhadap nyeri post sectio caesaria yang menggunakananalisis uji wilcoxon dengan hasil $p$ value $0,000<0,05$ sehingga diketahui ada pengaruh terhadap penurunan nyeri post sectio caesaria sebelum dan sesudah diberikan aromaterapi kenanga menggunakan teknik inhalasi. Untuk nyeri yang dirasakan pasien sebelum melakukan penghirupan aromaterapi kenanga adalah rata-rata 5,000 (nyeri sedang) dan sesudah 3,25 (nyeri ringan).

Aromaterapi merupakan sebuah metode penyembuhan menggunakan minyak esensial. Minyak esensial yang digunakan adalah minyak kenanga. Teknik yang digunakan dalam pemberian aromaterapi kenanga dalam menurunkan nyeri pada pasien post sectio caesaria adalah inhalasi. Inhalasi adalah cara penyembuhan langsung dan paling cepat, karena molekul yang mudah menguap dibawa oleh arus udara menuju hidung dimana silia-silia yang lembut muncul dari sel-sel reseptor dan pesan elektrokimia akan ditransmisikan melalui olfactory kedalam sistem limbik yang merangsang memori dan respin emosional, pesan tersebut disampaikan ke otak dan diubah menjadi tindakan yang berupa neurokimia yang menyebabkan euphoria, relaks dan sedative (Koensoemardiyah, 2009).

Aromaterapi merupakan suatu metode yang menggunakan minyak esensial untuk meningkatkan kesehatan fisik dan juga mempengaruhi kesehatan emosi seseorang. Minyak esensial adalah minyak alami yang diambil dari tanaman aromatik (Koensoemardiyah, 2009). Aromaterapi berasal dari kata aroma yang berarti harum 
atau wangi dan Therapy yang dapat diartikan sebagai suatu cara pengobatan atau penyembuhan. Sehingga dapat diartikan sebagai suatu cara perawatan tubuh dan atau penyembuhan penyakit dengan menggunakan minyak esensial (essential oil) (Jaelani, 2009). Oleh sebab itu, 24 orang responden dalam penelitian ini diberikan perlakuan berupa meghirup aromaterapi kenanga selama 5-10 menit menggunakan roll on, seluruhnya $(100 \%)$ menunjukkan penurunan yang signifikan, sehingga dapat disimpulkan bahwa aromaterapi kenanga melalui inhalasi menggunakan roll on dapat menurunkan tingkat nyeri pasien sectio caesaria dengan baik, $p$ value $=0,000$, yang mana lebih kecil nilainya dari 0,05 , sehingga kesimpulannya $\mathrm{H}_{0}$ ditolak yang berarti ada pengaruh pemberian aromaterapi kenanga terhadap penurunan nyeri pasien sectio caesaria .

Aromaterapi adalah terapi yang menggunakan minyak esensial atau sari minyak murni untuk membantu memperbaiki atau menjaga kesehatan, membangkitkan semangat, menyegarkan serta membangkitkan jiwa dan raga.Essential oil atau minyak esensial yang digunakan merupakan cairan hasil sulingan dari berbagai jenis bunga, akar, pohon, biji, getah, daun dan rempah-rempah yang memiliki khasiat untuk pengobatan (Hutasoid, 2002).

Kenanga (Canangium Odoratum) adalah tumbuhan berbatang besar sampai diameter 0,1-0,7 meter dengan usia puluhan tahun. Tumbuhan kenanga mempunyai batang yang mudah patah pada waktu mudanya.Tinggi pohon ini dapat mencapai 5-20 meter. Bunga kenanga akan muncul pada batang pohon atau ranting bagian atas pohon dengan susunan bunga yang spesifik. Bunga kenanga terdiri dari 6 lembar daun dengan mahkota berwarna kuning serta dilengkapi 3 lembar daun berwarna hijau (Suparni \& Ari, 2012).

Bunga kenanga beraroma harum dan khas. Tumbuhan dari familyannonaceae ini diduga berasal dari Asia Tenggara termasuk Indonesia. Karena baunya yang harum, ia dikenal sebagai pohon parfum. Bunga ini mengandung asam bensoat, farnesol, geraniol, linalool, bensin asetat, eugenol, sadrol, kadinen, dan pinen. Kandungan minyaknya yang cukup tinggi namun mudah sekali menguap.(Suparni \& Ari, 2012).

Penelitian tentang penggunaan minyak aromaterapi kenanga terhadap nyeri persalinan memang belum banyak di lakukan tetapi minyak ini sudah digunakan untuk pengobatan dan diperlukan penelitian lebih lanjut lagi terhadap manfaat yang terkandung pada aromaterapi kenanga, sehingga didukung oleh riset bahwa memang aromaterapi ini mempunyai efek yang sama dengan aromaterapi lavender yang memang sudah banyak dipergunakan dalam pengobatan maupun perawatan karna mempunyai kandungan Bunga ini mengandung asam bensoat, farnesol, geraniol, linalool, bensin asetat, eugenol, sadrol, kadinen, dan pinen. Kandungan minyaknya yang cukup tinggi namun mudah sekali menguap membuat yang mencium aroma memberikan rasa nyaman serta relaksasi pada tubuh dan fikiran, rasa nyeri dan cemas akan tereduksi sehingga nyeri akan berkurang. Bunga kenanga juga sering digunakan dalam dunia pengobatan herbal, dimana bunga ini mengandung senyawa aktif berguna seperti flavonoid, Saponin, polifenol, minyak atsiri, eugenol, dan geraniol (Suparni \& Ari, 2012).

\section{Perbandingan Aromaterapi Kenanga Dengan Aromaterapi Lavender Menggunakan Teknik Inhalasi dalam penurunan nyeri post sectio caesaria}

Berdasarkan tabel 5 yang membandingkan aromaterapi kenanga dibandingkan dengan lavender, didapatkan bahwa tidak ada perbedaan yang signifikan dari kedua 
kelompok tersebut dan artinya kedua aromaterapi dan teknik inhalasi tersebut mempunyai pengaruh yang sama dalam penurunan intensitas nyeri post sectio sesarea hal ini dibuktikan dengan analisis uji statistik mann-whitneydiperoleh $p$ value $0,054>0,05$. Berdasarkan pengamatan yang dilakukan pada saat penelitian beberapa pasien lebih menyukai teknik inhalasi karena lebih mudah dilakukan sendiri.

Aromaterapi merupakan penggunaan minyak esensial untuk tujuan penanganan yang meliputi: pikiran, tubuh, dan semangat. Aromaterapi dalam keperawatan didefinisikan sebagai penggunaan minyak esensial untuk hasil kesehatan yang diharapkan (Halson dan Buckle, 2006). Aromaterapi adalah terapi yang menggunakan minyak esensial atau sari minyak murni untuk membantu memperbaiki atau menjaga kesehatan, membangkitkan semangat, menyegarkan serta membangkitkan jiwa dan raga. Essential oil atau minyak esensial yang digunakan merupakan cairan hasil sulingan dari berbagai jenis bunga, akar, pohon, biji, getah, daun dan rempah-rempah yang memiliki khasiat untuk pengobatan (Hutasoid, 2002).

Aromaterapi kenanga dapat memberikan efek rileks dan mengurangi ketegangan pada tubuh, terutama untuk terapi yang bersifat psikis atau emosional.Ditambahkan bahwa minyak kenanga juga sangat baik untuk terapi aroma (aromaterapi). Aromaterapi akan mengatur aliran kelenjar adrenalin dalam sistem saraf sehingga menimbulkan perasaan senang, tenang, menghilangkan rasa gelisah, marah, dan panik (Wahyu, 2011).

Kenanga (Canangium Odoratum) adalah tumbuhan berbatang besar sampai diameter 0,1-0,7 meter dengan usia puluhan tahun. Tumbuhan kenanga mempunyai batang yang mudah patah pada waktu mudanya. Tinggi pohon ini dapat mencapai 5-20 meter. Bunga kenanga akan muncul pada batang pohon atau ranting bagian atas pohon dengan susunan bunga yang spesifik. Bunga kenanga terdiri dari 6 lembar daun dengan mahkota berwarna kuning serta dilengkapi 3 lembar daun berwarna hijau (Suparni \& Ari, 2012).

Bunga kenanga beraroma harum dan khas. Tumbuhan dari familyannonaceae ini diduga berasal dari Asia Tenggara termasuk Indonesia. Karena baunya yang harum, ia dikenal sebagai pohon parfum. Bunga ini mengandung asam bensoat, farnesol, geraniol, linalool, bensin asetat, eugenol, sadrol, kadinen, dan pinen. Kandungan minyaknya yang cukup tinggi namun mudah sekali menguap. Bunga kenanga juga sering digunakan dalam dunia pengobatan herbal, dimana bunga ini mengandung senyawa aktif berguna seperti flavonoid, Saponin, polifenol, minyak atsiri, eugenol, dan geraniol (Suparni \& Ari, 2012).

Minyak lavender merupakan minyak hasil ekstraksi dengan destilasi uap bunga dari tanaman Lavandula agustifolia P. Miller (suku Lamiaceae).Lavandula agustifolia merupakan tanaman dengan tinggi 1-2 $\mathrm{m}$. Susunan bunganya mengumpul di tengah dengan jumlah 6-8 bunga pada setiap gerombolannya. Bunga berwarna ungu kecil-kecil dengan panjang 2-8 $\mathrm{cm}$ dengan kebiruan di ujung daun dan mengeluarkan aroma wangi. Daunnya berukuran 2-6 $\mathrm{cm}$ dan lebar 4-6 mm, bertulang sejajar, tangkai daunnya pendek dan berwarna hijau dan tumbuh di ujung batang bunga. Batangnya berwarna coklat abu-abu atau coklat gelap dengan kulit kayunya mempunyai pola memanjang sesuai dengan batang kayunya.Tanaman ini tumbuh liar di Indonesia, hanya membutuhkan sedikit air, tetapi tidak tumbuh baik di tanah yang selalu lembab. Tanaman ini sering dipakai sebagai tanaman hias (WHO monographs, 2007).

Dalam bidang penelitian penggunaan aromaterapi lavender memang sudah banyak dilakukan sedangkan untuk penggunaan aromaterapi kenanga dalam pengobatan maupun perawatan memang sudah dilakukan tetapi masih sedikit. Tetapi 
dalam penelitian ini aromaterapi lavender dan kenangan menurunkan intensitas nyeri post section caesaria.karna di kedua tanaman ini mengandung zat flavonoid karna aktivitas zat flavonoid adalah sebagai zat anti depresan, anti inflamasi, analgesic dan anti oksidan karna menghirup Bungan tersebut akan meningkatkan gelombang alfa didalam otak dan hal ini lah yang membuat kita akan rilek.akan menurunkan intensitas nyeri (Jaelani, 2009)

\section{SIMPULAN}

Hasil analisis dengan uji Wilcoxon didapatkan $p$ value 0,000 pada kedua kelompok intervensi aromaterapi lavender dan kelompok intervensi aromaterapi kenanga dengan teknik inhalasi. Hasil ini menunjukkan bahwa ada pengaruh secara signifikan intervensi aromaterapi lavender dan kenanga terhadap intensitas nyeri pasien post sectio caesaria. Hasil analisis menggunakan uji Mann-Whitney menunjukkan $p$ value $0,054>0,05$, artinya tidak ada perbedaan pengaruh yang signifikan pada kelompok kenanga dan lavender. Kedua minyak aromaterapi tersebut mampu menurunkan intensitas nyeri pada pasien post sectio caesaria .

\section{SARAN}

Pada ibu post sectio caesaria dapat menggunakan alternatif untuk mengurangi intensitas nyeri dengan penggunaan aromaterapi. Aromaterapi yang digunakan bisa disesuaikan dengan selera masing-masing individu karena baik aromaterapi kenanga maupun lavender mempunyai efek yang sama dalam penurunan intensitas nyeri.

\section{DAFTAR PUSTAKA}

Apay, S.E., Arslan, S., Akpinar, R.B., Celebioglu, A. (2012). Effect of Aromatherapy Massage on Dysmenorrhea in Turkish Students.The American Society for Pain Management Nursing.

Asmadi.(2008). Teknik Prosedural Keperawatan Konsep dan Aplikasi Kebutuhan Dasar Klien. Jakarta: Salemba Medika.

Bakir, R.S. 2009. Aroma Terapi. Tangerang: Karisma.

Baehr M. Diagnosis Topik Neurologi DUUS. Jakarta: EGC. 2010.

Care Management Guidelines. (2005). Pain Management International association for the study of Pain (IASP). Palliative Care. Departemen of Health and Human Service.

Dahlan, M. Sopiyudin. (2013). Statistik Untuk Kedokteran dan Kesehatan:Deskriptif, Bivariat, dan Multivariat, Dilengkapi Aplikasi dengan Menggunakan SPSS. Jakarta: Salemba Medika.

Dewi, Y. (2007). Operasi Caesar, Pengantar dari A sampai Z. Jakarta: EDSA Mahkota.

Dwijayanti W., Sumarni S., Ariyanti. (2014). Efek Aromaterapi Lavender Inhalasi terhadap Intensitas Nyeri Pasca Sectio caesaria . Medica Hospitalia 2 (2); 120 125

Dean, S. (2007). PedomanMenjadiSehatbagi Orang Sibuk : Aromaterapi. Batam Centre: Karisma Publishing Group. 
Halcon, L.L., Buckle, J. (2006). Aromatherapy.Complementary/Alternative Therapies in Nursing. 5th Edition Chapter 26. Springer Publishing Company, Inc. New York.

Hutasoid, A. (2002). Panduan Praktis Aromatherapy Untuk Pemula.Cara mudah Memanfaatkan wewangian alami untuk keselarasan Pikiran, Jiwa dan Raga. Jakarta: Gramedia Pustaka Utama.

Hur, M.H., Lee, M.S., Seong, K.Y., Lee, M.K. (2011). Aromatherapy Massage on the Abdomen for Alleviating Menstrual Pain in High School Girls: A Preliminary Controlled Clinical Study. Journal Complementary and Alternative Medicine.

Jaelani.(2009). Aromaterapi. Jakarta: Pustaka Populer Obor.

Judha M. Sudarti \& Fauziah A. (2012).Teori Pengukuran Nyeri dan Nyeri Persalinan. Yogyakarta: Nuha Medika.

Koensoemardiyah.(2009). A-Z Aromaterapi (Untuk Kesehatan, Kebugaran dan Kecantikan). Yogyakarta: Lily Publisher.

Notoatmodjo, S (2010). Metodologi Penelitian Kesehatan. Jakarta: Rineka Cipta.

Otto, S.E. (2003).Buku Saku Keperawatan Onkologi. Jakarta: EGC.

Potter and Perry.(2006). Buku Ajar Fundamental Keperawatan (Edisi 4). Jakarta: EGC.

Prawirohardjo, S. (2009). Ilmu Kebidanan. Jakarta: EGC.

Praptiani, W. (2012). Kebidanan Oxford dari Bidan untuk Bidan. Jakarta:EGC.

Raphael, A. (2002). Aromatherapy.Handbook of Complementary and Alternative Therapies in Mental Health.International Journal of Aromatherapy.

Reeder, Martin \& Koniak-Griffin.(2011). Keperawatan Maternitas: Kesehatan Wanita, Bayi, \& Keluarga. Jakarta: EGC.

Suparni, Ari Wulandari. (2012). Herbal Nusantara: 1001 Ramuan Tradisional Asli Indonesia. Yogyakarta: Rapha Publishing.

Tamsuri, A. (2007). Konsep dan Penatalaksanaan Nyeri.Jakarta : EGC.

World Health Organization.(2007). WHO Monographs on Selected Medicinal Plants Vol 3. Ottawa: WHO.

Widayani W. (2016). Aromaterapi Lavender dapat Menurunkan Intensitas Nyeri Perineum pada Ibu Post Partum. Jurnal Ners dan Kebidanan Indonesia. 